\title{
Analisis Pola Rekrutmen Tenaga Pendidik
}

\author{
Hidayat $^{1}$, Asriyantini ${ }^{2}$ \\ ${ }^{1,2}$ Jurusan Manajemen Pendidikan Islam Fakultas Ilmu Tarbiyah dan Keguruan \\ Universitas Islam Negeri Raden Fatah Palembang Sumatera Selatan \\ Email: hidayat@radenfatah.ac.id
}

\begin{tabular}{l} 
Info Artikel \\
\hline Sejarah Artikel: \\
Diterima: Juli 2020 \\
Disetujui: Agustus 2020 \\
Dipublikasikan: September \\
2020
\end{tabular}

Kata kunci:

Analisis, Rekrutmen,

Tenaga Pendidik

Keywords:

Analysis, Recruitment, Teaching Staff

\begin{abstract}
ABSTRAK
Penelitian ini berjudul Pola Rekrutmen Tenaga Pendidik di MTs 'Aisyiyah 1 Palembang. Adapun tujuan dari penelitian ini adalah untuk mengetahui pola rekrutmen tenaga pendidik di MTs 'Aisyiyah 1 Palembang. Dalam penelitian ini peneliti menggunakan penelitian kualitatif. Informan Penelitian yang dilakukan dalam penelitian ini yaitu kepala sekolah MTs "Aisyiyah 1 Palembang dan kepala tata usaha sebagai key infornan dan waka-waka sekolah serta tenaga pendidik sebagai informan pendukung. Teknik pengumpulan data dalam penelitian ini melalui observasi, wawancara, dan dokumentasi. Teknik analisis data dilakukan dengan reduksi data, penyajian data, verikasi atau penarikan kesimpulan. Hasil penelitian menunjukkan bahwa Pola Rekrutmen tenaga Pendidik di MTs 'Aisyiyah 1 Palembang dari proses perencanaan rekrutmen tenaga pendidik, evaluasi sumber-sumber tenaga pendidik, penentuan kebutuhan tenaga pendidik seleksi, penempatan, orientasi tenaga pendidik sudah cukup baik. Karena sekolah sudah melakukan proses perencanaan rekrutmen tenaga pendidik sampai kegiatan orientasi tenaga pendidik, namun kurang dalam proses pengawasan yang dilakukan kepala sekolah karena, masih ditemukan tenaga pendidik yang mengajar bukan pada keilmuannya serta masih ada tenaga pendidik yang memiliki tugas lebih dari satu sehingga kurangnya akan keprofesionalismenya, sehingga menyebabkan proses pengelolaan tenaga pendidik belum maksimal.
\end{abstract}

\section{ABSTRACT}

This study is entitled The Recruitment Pattern of Educators in MTs 'Aisyiyah 1 Palembang. The purpose of this study was to determine the recruitment patterns of teaching staff at MTs 'Aisyiyah 1 Palembang. In this study researchers used qualitative research. Informants The research conducted in this study were the headmaster of MTs 'Aisyiyah 1 Palembang and the head of administration as key informants and school officials and educators as supporting informants. Data collection techniques in this study through observation, interviews, and documentation. Data analysis technique is done by data reduction, data presentation, verification or conclusion drawing. The results showed that the Pattern of Recruitment of Educators in MTs isy Aisyiyah 1 Palembang from the planning process of recruitment of educators, evaluating the sources of educators, determining the needs 
of educators for selection, placement, orientation of educators was quite good. Because the school has carried out the planning process for the recruitment of educators to the orientation activities of the teaching staff, but it is lacking in the supervision process carried out by the school principal, because there are still teaching staff who teach not on their knowledge and there are still educators who have more than one task so there is a lack of professionalism. thus causing the management process of teaching staff not yet maximized.

(C) 2020 Hidayat, Asriyantini Under The License CC-BY SA 4.0

\section{PENDAHULUAN}

Pola merupakan bentuk atau model (suatu set peraturan) yang bisa dipakai untuk membuat atau untuk menghasilkan suatu atau bagian dari suatu. Proses rekrutmen merupakan rangkaian kegiatan untuk mendapatkan tenaga kerja dengan prospektif masa depan yang positif. Untuk itu organisasi harus selalu berusaha menyesuaikan kebijaksanaan rekrutmen untuk merespon perubahan dan perkembangan pasar tenaga kerja (Samsudin, 2006, p. 87). Pola rekruitmen yang baik dan benar, akan memperoleh guru yang berkualitas membantu siswa atau peserta didik untuk lebih berkembang. Salah satu tujuan dan rekruitmen tenaga pendidik agar dapat mengetahui kualitas dan guru yang akan mengajar siswa. Harapannya agar dapat terciptanya prestasi siswa (Murnawati, 2014)

Rekrutmen diartikan sebagai pencarian dan pengadaan calon sumber daya manusia yang berkualitas dan potensial, sehingga dapat diseleksi orang-orang yang paling tepat bagi kebutuhan kerja yang ada (Ulfa \& Irawan, 2018). Menyadari pentingnya keberadaan tenaga pendidik di sekolah, maka perlu dilakukan rekrutmen yang benar. Rekrutmen tenaga pengajar dilakukan berdasarkan atas kebutuhan tenaga pengajar di suatu lembaga pendidikan (Murnawati, 2014). Menurut Maryono mengatakan rekruitmen merupakan proses mencari,menemukan, dan menarik para pelamar untukdipekerjakan dalam dan oleh suatu lembaga (Maryono, 2015) 
Menurut Yunarsih dan Suwatno menyatakan bahwa perekrutan merupakan kegiatan untuk mendapatkan sejumlah pegawai dari berbagai sumber, sesuai dengan kualifikasi yang dibutuhkan sehingga mereka mampu menjalankan misi organisasi atau lembaga untuk merealisasikan visi dan tujuannya (Sinambela, 2017, p. 120).

Sedangkan menurut Sadili Samsudin, rekrutmen adalah proses mencari, menemukan, mengajak, dan menetapkan sejumlah orang dalam maupun luar organisasi sebagai calon tenaga kerja dengan karakteristik tertentu seperti yang telah ditetapkan dalam perencanaan sumber daya manusia (Supomo, 2018, p. 42)

Pola rekrutmen tenaga pendidik menurut Mathis dan Jackson yang dikutip oleh Lijan Poltak adalah sebagai berikut: Perencanaan atau Identifikasi rekrutmen SDM, Evaluasi sumber-sumber rekrutmen Tenaga Pendidik, Penentuan kebutuhan tenaga pendidik, Seleksi tenaga pendidik, Penempatan tenaga pendidik, Orientasi tenaga pendidik (Sinambela, 2017, p. 120). Proses rekrutmen tenaga pendidik dalam lembaga pendidikan di sekolah adalah berusaha mencari guru yang memiliki kompetensi, kecakapan dan ahli dalam mendidik dan mengajar sesuai bidangnya di samping itu yang sangat penting dimiliki oleh seorang guru adalah sifat jujur serta memiliki jasmani yang sehat sehingga dapat menjalankan tugasnya dalam mencerdaskan anak bangsa (Rahman, Ardiansyah, \& Marwazi, 2015).

Pelaksanaan rekrutmen merupakan tugas yang sangat penting, krusial dan membutuhkan tanggung jawab yang besar. Hal ini karena kualitas sumber daya manusia yang akan digunakan sekolah sangat bergantung pada prosedur rekrutmen dan seleksi yang dilaksanakan (Isnaini, 2015). Keberhasilan sekolah untuk mendapatkan sumber daya manusia yang berkualitas tidak lepas dari upaya pihak sekolah untuk mengadakan rekrutmen yang baik. Di mana dengan melalui proses rekrutmen ini dapat menghasilkan satu kelompok pelamar yang memenuhi syarat untuk bekerja di lembaga pendidikan tersebut. Semua kegiatan tersebut akhirnya akan terpulang kepada sejumlah orang (tenaga kependidikan) yang terlibat. Oleh karena itu peran mereka sangat menentukan gagal atau berhasilnya pelaksanaan tugas. Mereka itu haruslah dipersiapkan secara khusus, terpelajar dan terpilih (Nurhayanti \& Fadila, 2018). Pendidik adalah pendidik yang menjadi tokoh, 
panutan, dan identifikasi bagi para peserta didik dan lingkungannya. Oleh karena itu pendidik harus memiliki standar kualitas pribadi tertentu yang mencakup tanggung jawab wibawa, mandiri dan disiplin (Sudiartono, 2020)

Berdasarkan fakta dilapangan proses rekrutmen tenaga pendidik di MTs 'Aisyiyah 1 Palembang belum begitu terlaksana dengan baik, hal ini tercermin dari hasil observasi peneliti pada 3 Oktober 2018, pukul 13:00 WIB, melalui wawancara peneliti dengan salah satu guru mengatakan bahwa proses rekrutmen belum begitu maksimal dan tidak melakukan tahap khusus dalam rekrutmen tenaga pendidik, seperti pada saat ini jika ada rekrutmen tenaga pendidik itu dilakukan si pelamar secara langsung datang ke sekolah dengan membawa berkas-berkas yang diperlukan tanpa tahu sekolah mengadakan rekrutmen atau tidak. Pada saat penempatan tenaga pendidik juga, sekolah tidak melihat latar belakang pendidikan yang dimilikinya, terbukti secara langsung terdapat beberapa guru yang memiliki tanggung jawab yang tidak sesuai dengan kemampuan yang dimilikinya dan bahkan memiliki tanggung jawab tugas yang berganda, sehingga tidak maksimal dalam menjalankan tugasnya. Selain itu juga tidak tersedianya tenaga kerja yang ahli dalam bidang manajemen SDM (Rekrutmen), sebagai penunjang berjalannya proses rekrutmen atau manajemen tenaga pendidik di lembaga.

Menurut Lisnandari dalam penelitiannya bahwa hasil Rekrutmen Tenaga Pendidik Madrasah Aliyah Al-Inaayah Depok Pakenjeng Garut. a. Segi Kuantitatif Pencapaian Rekrutmen yang dilaksanakan Madrasah Aliyah Al-Inaayah menghasilkan 23 tenaga pendidik yang memiliki kompetensi yang profesional. Adapun tenaga pendidik yang profesional adalah sebagai berikut: 1) Kompetensi pedagogik 2) Kompetensi kepribadian. 3) Kompetensi Sosial. 4) Kompetensi profesional. b. Segi Kualitatif di Madrasah Aliyah Al-Inaayah Keberhasilan Rekrutmen Tenaga Pendidik (Lisnandari, 2018).

Berdasarkan Undang-Undang Republik Indonesia Nomor 20 Tahun 2003 tentang Sistem pendidikan Nasional merupakan dasar hukum penyelenggaraan dan reformasisystem pendidikan nasional, maka dalam lembaga pendidikan harus diterapkan manajemen sumber daya manusia dengan baik. Agar supaya,seluruh 
sumber daya kependidikan yangberada di dalamnya dapat diberdayakan dengan baik. Sehingga, dapat meningkatkan kinerja tenaga kependidikan pada lembaga pendidikan tersebut (Undang-UndangSistemPendidikanNasional(SISDIKNAS), Nomor 20 Tahun 2003).

Dalam hal ini, dapat ditarik kesimpulan bahwa disetiap proses pendidikan di lembaga perlu adanya manajemen sekolah yang baik, mulai dari proses perencanaan rekrutmen, evaluasi sumber-sumber rekrutmen tenaga pendidik sampai orientasi tenaga pendidik, dengan begitu tujuan pendidikan dapat tercapai secara optimal. Dimana pada dasarnya keberhasilan dalam pendidik dimulai dari tenaga pendidik atau sumber daya manusia itu sendiri, karena tenaga pendidik merupakan orang yang bertanggung jawab dalam melaksanakan dan menyampaikan pembelajaran sesuai tujuan pembelajaran yang telah ditetapkan, jadi jika pola rekrutmen tenaga pendidik dilakukan sebagai mestinya maka tujuan pendidikan dapat tercapai sesuai yang diinginkan.

\section{METODE PENELITIAN}

Dalam penelitian ini Pola rekrutmen tenaga pendidik mengutip dari teori yang dikemukakan oleh Mathis dan Jackson yang dikutip oleh Lijan Poltak adalah sebagai berikut: Perencanaan atau Identifikasi rekrutmen SDM, Evaluasi sumber-sumber rekrutmen Tenaga Pendidik, Penentuan kebutuhan tenaga pendidik, Seleksi tenaga pendidik, Penempatan tenaga pendidik, Orientasi tenaga pendidik (Sinambela, 2017, p. 120).

Jenis penelitian yang digunakan dalam penelitian ini adalah jenis penelitian kualitatif. Adapun pendekatan penelitian adalah dengan pendekatan studi kasus. Jenis data dalam penelitian ini adalah data kualitatif. Adapun yang menjadi sumber data dalam informan ini yaitu: informan kunci dan informan pendukung: Informan kunci dalam penelitian ini adalah Kepala sekolah, Ketua staf tata usaha. Informan pendukung dalam penelitian ini adalah wakil kurikulum, tenaga pendidik, dan semua stekholder yang mendukung. 
Teknik pengumpulan data dalam penelitian ini teknik pengumpulan data yang dilakukan adalah wawancara, observasi, dan dokumentasi. Teknik analisa data, Reduksi Data (Data Reduction), Penyajian data (Data Display), Verifikasi/Penarikan kesimpulan.

\section{HASIL PENELITIAN}

1. Identifikasi atau Perencanaan rekrutmen tenaga pendidik

Identifikasi atau perencanaan yang dilakukan sekolah sepenuhnya dilakukan oleh kepala sekolah melibatkan peran serta waka-waka, kepala tata usaha dan yayasan sekolah dalam menyusun rencana rekrutmen tenaga pendidik, yang dilakukan setiap awal tahun atau tahun ajaran baru dimana sekolah membutuhkan tenaga pendidik.Selain itu proses perencanaan yang dilakukan sekolah juga memperhatikan berbagai macam aspek seperti jumlah tenaga pendidik yang dibutuhkan, komitmen terhadap sekolah, serta kualitas tenaga pendidik yang harus strata 1 (S1), barulah sekolah melakukan pemberitaan bahwa sekolah akan menerima tenaga pendidik yang baru melalui pengumuman website facebook sekolah.

2. Evaluasi Sumber-sumber Penarikan Tenaga Pendidik

Evaluasi sumber-sumber rekrutmen tenaga pendidik di sekolah yang dilakukan kepala sekolah sendiri itu kurang pengawasan, karena pada saat penempatan tidak sesuai dengan latar belakang pendidikan tenaga pendidik tersebut. Pada saat menerima tenaga pendidik bersumber atas kekerabatan atau kenalnya pihak sekolah dengan tenaga pendidik.

3. Penentuan Kebutuhan Tenaga Pendidik

Penentuan kebutuhan tenaga pendidik di Madrasah Tsanawiyah 'Aisyiyah 1 Palembang yang dilakukan oleh Kepala Madrasah sudah cukup baik, karena pada saat penentuan kebutuhan tenaga pendidik itu dilakukan sesuai prosudur yang ada di Madrasah.

4. Seleksi Tenaga Pendidik

Seleksi pelamar atau tenaga pendidik yang baru harus mengantarkan berkas lamarannya sendiri ke sekolah karena setelah berkas dikumpulkan kepala sekolah 
akan melakukan wawancara terhadap tenaga pendidik yang baru setelah iu sekolah dalam hal ini kepala sekolah akan menentukan diterima atau tidaknya tenaga pendidik yang baru melamar setelah wawancara akan dihubungi kembali oleh pihak sekolah untuk mendapat jawaban atas proses seleksi.

\section{Penempatan tenaga pendidik}

Penempatan tenaga pendidik di sekolah maka penulis dapat menganalisis bahwa, proses penempatan tenaga pendidik yang dilakukan oleh kepala sekolah pertama dalam penempatan tenaga pendidik mayoritas sudah strata 1 (S1), namun ada tenaga pendidik yang sudah S1 tetapi tidak ditempatkan sesuai latar belakang keilmuannya seperti ibu Liza dengan latar belakang pendidikan ekonomi yang ditempatkan sebagai guru bahasa arab, serta ada 3 tenaga pendidik yang memiliki tugas berganda yang ditempatkan oleh kepala sekolah kurang maksimal dan tidak sesuai teori dimana proses penempatan yang baik tenaga pendidik harus ditempatkan sesuai latar belakang keilmuan.

\section{Orientasi Tenaga Pendidik}

Orientasi tenaga pendidik di sekolah sudah ada dan dilakukan pada saat rapat guru di sekolah, biasanya dilakukan dengan waktu relatif singkat. Kepala sekolah juga memberikan waktu 3 bulan sebagai bentuk adaptasi tenaga pendidik baru terhadap tenaga pendidik lainnya dan juga murid-murid di sekolah. Sehingga proses orientasi yang dilakukan oleh sekolah khususnya kepala sekolah sudah berjalan dengan baik walaupun dalam waktu yang cukup singkat dan belum begitu diterapkan secara maksimal.

\section{PEMBAHASAN}

\section{Perencanaan atau Identifikasi rekrutmen SDM}

Perencanaan rekrutmen tenaga pendidik adalah pengembangan dan strategi dan penyusunan tenaga pendidik (Sumber Daya Manusia/SDM) yang komperhensif guna memenuhi kebutuhan organisasi di masa depan. Perencanaan rekrutmen SDM merupakan proses menentukan kebutuhan tenaga kerja yang akan ditarik atau direkrut(Mangkunegara, 2015). 
Kepala madrasah harus melakukan tindakan saat melihat adanya kekosongan di madrasah dengan melakukan rencana untuk membuat informasi tentang rekrutmen tenaga pendidik baru yang akan mengisi kekosongan sesuai kriteria jabatan yang kosong di madrasah. Dalam rangka menjamin efektifitas dan efisiensi, penarikan jumlah tenaga pendidik harus sesuai dengan kebutuhan tidak lebih dan tidak kurang, demikian juga kualitas tenaga pendidik yang dibutuhkan harus dapat melaksanakan tugas-tugas, baik tugas pokok, fungsional, ataupun administratif di madrasah.

Kepala sekolah melibatkan peran serta waka-waka, kepala tata usaha dan yayasan sekolah dalam menyusun rencana rekrutmen tenaga pendidik, yang dilakukan setiap awal tahun atau tahun ajaran baru dimana sekolah membutuhkan tenaga pendidik.Selain itu proses perencanaan yang dilakukan sekolah juga memperhatikan berbagai macam aspek seperti jumlah tenaga pendidik yang dibutuhkan, komitmen terhadap sekolah, serta kualitas tenaga pendidik yang harus strata $1(\mathrm{~S} 1)$.

2. Evaluasi sumber-sumber rekrutmen Tenaga Pendidik

Evaluasi sebagai alat untuk memastikan sumber-sumber penarikan dapat mendukung dan memenuhi kebutuhan dalam pelaksanaan proses rekrutmen sampai pada seleksi dan penempatan. Kegiatan evaluasi dapat membantu memudahkan dalam penentuan pekerjaan dan penempatan pelamar sesuai bidangnya. Secara terinci, sukses fungsi penarikan dapat dinilai dengan menggunakan sejumlah kriteria (Samsudin, 2006). Proses evaluasi sumber-sumber rekrutmen tenaga pendidik di sekolah yang dilakukan kepala sekolah sendiri itu kurang pengawasan, karena pada saat penempatan tidak sesuai dengan latar belakang pendidikan tenaga pendidik tersebut. Pada saat menerima tenaga pendidik bersumber atas kekerabatan atau kenalnya pihak sekolah dengan tenaga pendidik.

3. Penentuan kebutuhan tenaga pendidik

Setiap lembaga mempunyai kebutuhan untuk mencapai tujuan sesuai visi misinya. Kebutuhan tersebut bisa berupa kebutuhan fisik maupun kebutuhan sumber daya manusia yang dapat membantu menyelesaikan persoalan-persoalan serta pekerjaan-pekerjaan yang menjadi tugas organisasi atau lembaga (Samsudin, 2006). 
Proses penentuan kebutuhan tenaga pendidik di Madrasah yang dilakukan Kepala Madrasah sudah cukup baik, karena pada saat penentuan kebutuhan tenaga pendidik itu dilakukan sesuai prosudur yang ada di Madrasah.

4. Seleksi tenaga pendidik

Seleksi merupakan proses di mana organisasi-organisasi memutuskan orang yang akan atau tidak akan diizinkan masuk ke organisasi/lembaga. Beberapa standar umum harus dipenuhi pada proses seleksi apapapun (Supomo, 2018)Seleksi tenaga pendidik merupakan bagian dari proses pengelolaan dimana setelah dilakukan proses perencanaan, rekrutmen barulah masuk ke dalam tahap seleksi tenaga pendidik. Seleksi tenaga pendidik merupakan tahap dimana seseorang atau tenaga pendidikan baru akan diterimaatau tidak di dalam suatu organisasi khususnya sekolah.

Proses seleksi pelamar atau tenaga pendidik yang baru harus mengantarkan berkas lamarannya sendiri ke sekolah karena setelah berkas dikumpulkan kepala sekolah akan melakukan wawancara terhadap tenaga pendidik yang baru setelah iu sekolah dalam hal ini kepala sekolah akan menentukan diterima atau tidaknya

5. Penempatan tenaga pendidik

Penempatan tenaga pendidik dapat diartikan sebagai tindak lanjut dari proses seleksi tenaga pendidik, yaitu menempatkan tenaga pendidik yang diterima pada jabatan/pekerjaan yang membutuhkannya (Yuniarsih, 2011).

Penempatan tenaga pendidik merupakan rangkaian dalam proses pengelolaan tenaga pendidik dimana proses penempatan merupakan tindak lanjut dari tahap seleksi dan orientasi. Dalam proses penempatan tenaga pendidik yang harus diperhatikan adalah latar belakang pendidikan tenaga pendidik, kinerja tenaga pendidik serta keterampilan tenaga pendidik dalam melaksanakan tugas yang telah diberikan.

Penempatan tenaga pendidik yang dilakukan oleh kepala sekolah pertama dalam penempatan tenaga pendidik mayoritas sudah strata 1 (S1), namun ada tenaga pendidik yang sudah S1 tetapi tidak ditempatkan sesuai latar belakang keilmuannya, dan tidak sesuai teori dimana proses penempatan yang baik tenaga pendidik harus ditempatkan sesuai latar belakang keilmuan. 


\section{Orientasi tenaga pendidik}

Orientasi adalah pengenalan dan adaptasi terhadap sebuah situasi atau lingkungan baru (Ulfatin, 2016). Orientasi merupakan bagian dari proses pengelolaan tenaga pendidik dimana proses orientasi ini penting bagi tenaga pendidik yang baru untuk mengenal lingkungan tempat bekerjanya yang baru setelah diterima atau lulus dalam tahap seleksi maka orientasi tenaga pendidik perlu agar mampu beradaptasi dengan lingkungan kerjanya yang baru, tentang tugas-tugas baru yang harus dikerjakan.

Kepala sekolah juga memberikan waktu 3 bulan sebagai bentuk adaptasi tenaga pendidik baru terhadap tenaga pendidik lainnya dan juga murid-murid di sekolah. Sehingga proses orientasi yang dilakukan oleh sekolah khususnya kepala sekolah sudah berjalan dengan baik walaupun dalam waktu yang cukup singkat dan belum begitu diterapkan secara maksimal.

\section{SIMPULAN}

Hasil penelitian tentang pola rekrutmen tenaga pendidik dapat disimpulkan bahwa rekrutmen tenaga pendidik di MTs 'Aisyiyah 1 Palembang dari proses perencanaan rekrutmen, penentuan kebutuhan tenaga pendidik, penempatan seleksi, orientasi kurang maksimal. Karena sekolah melakukan proses perencanaan rekrutmen tenaga pendidik sampai dengan orientasi tenaga pendidik, karena dalam hal ini kurangnya akan pengawasan yang dilakukan kepala sekolah, sebab telah ditemukan beberapa tenaga pendidik yang mengajar bukan pada keilmuannya serta memiliki tanggung jawab lebih dari satu, seperti ketua tata usaha bertugas menjadi tenaga pendidik, dalam hal ini keprofesionalisme tenaga pendidik kurang. Sehingga menyebabkan proses rekrutmen tenaga pendidik belum maksimal.

\section{REFERENSI}

Isnaini, R. L. (2015). Implementasi Rekrutmen Guru Disd Ta’Mirul Islam Surakarta (Kajian Manajemen Sumber Daya Manusia di SD Islam). Jurnal Pendidikan Agama Islam, 110-111.

Lisnandari. (2018). Manajemen Rekrutmen Tenaga Pendidik di Madrasah Aliyah . Jurnal Islamic Education Manajemen , 199-200. 
Mangkunegara. (2015). Manajemen Sumber Daya Manusia Perusahaan. Bandung: PT Rosda Karya.

Maryono. (2015). Sistem Rekruitmen, Seleksi, Penempatan dan Pembinaan Kepala Sekolah. Jurnal Manajer Pendidikan, 153.

Murnawati. (2014). Analisis Rekruitmen Tenaga Pendidik pada SD Kalam Kudus Pekanbaru . Jurnal Ilmiah Ekonomi dan Bisnis , 523.

Nurhayanti, H., \& Fadila, I. (2018). Recruitment Management Of Educators At The State Elementary School Of Sinduadi 1 Sleman Yogyakarta. National Seminar on Elementary Education, 341.

Rahman, K., Ardiansyah, \& Marwazi. (2015). Rekrutmen Tenaga Pendidik dalam Peningkatan Mutu Madrasah Aliyah Negeri Insan Cendekia Jambi . Nadwa Jurnal Pendidikan Islam , 24.

Samsudin, S. (2006). Manajemen Sumber Daya Manusia. Bandung: Pustaka Setia.

Siagian, S. P. (2016). Manajemen Sumber Daya Manusia. Jakarta: Bumi Aksara.

Sinambela, L. P. (2017). Manajemen Sumber Daya Manusia: Membangun Tim kerja yang Solid untuk Meningkatkan Kinerja. Jakarta: Bumi Aksara.

Sudiartono. (2020). Manajemen Tenaga Kependidikan di SMP Negeri Satap Tira. Jurnal PENDAIS, 91.

Supomo, R. (2018). Manajemen Sumber Daya Manusia. Bandung: Yrama Widya.

Ulfa, M., \& Irawan. (2018). Manajemen 'Ustāż dan `Ustāżah di Pesantren Modern . Madrasa Journal of Islamic Educational Management , 5.

Ulfatin, N. (2016). Manajemen Sumber Daya Manusi Bidang Pendidikan. Jakarta: PT Raja Grafindo Persada.

Undang-Undang Sistem Pendidikan Nasional (SISDIKNAS). (Nomor 20 Tahun 2003).

Yullyanti, E. (2009). Analisis Proses Rekrutmen dan Seleksi pada Kinerja Pegawai . Bisnis \& Birokrasi, Jurnal Ilmu Administrasi dan Organisasi, 131.

Yuniarsih, T. (2011). Manajemen Sumber Daya Manusia. Bandung: CV Alfabeta. 